\title{
Family Structure of The Malaysian Indian Youth Involved in Gangsterism
}

Veera Sundari Suppiah, Paramasivam Muthusamy \& Ismi Arif Bin Ismail

To Link this Article: http://dx.doi.org/10.6007/IJARBSS/v11-i19/11729 DOI:10.6007/IJARBSS/v11-i19/11729

Received: 13 October 2021, Revised: 30 October 2021, Accepted: 18 November 2021

Published Online: 20 December 2021

In-Text Citation: (Suppiah et al., 2021)

To Cite this Article: Suppiah, V. S., Muthusamy, P., \& Ismail, I. A. Bin. (2021). Family Structure of The Malaysian Indian Youth Involved in Gangsterism. International Journal of Academic Research in Business and Social Sciences, 11(11), 221-230.

Copyright: @ 2021 The Author(s)

Published by Human Resource Management Academic Research Society (www.hrmars.com)

This article is published under the Creative Commons Attribution (CC BY 4.0) license. Anyone may reproduce, distribute, translate and create derivative works of this article (for both commercial and non-commercial purposes), subject to full attribution to the original publication and authors. The full terms of this license may be seen

at: http://creativecommons.org/licences/by/4.0/legalcode

Special Issue Title: Youth and Community Wellness, 2021, Pg. 221 - 230

Full Terms \& Conditions of access and use can be found at http://hrmars.com/index.php/pages/detail/publication-ethics 


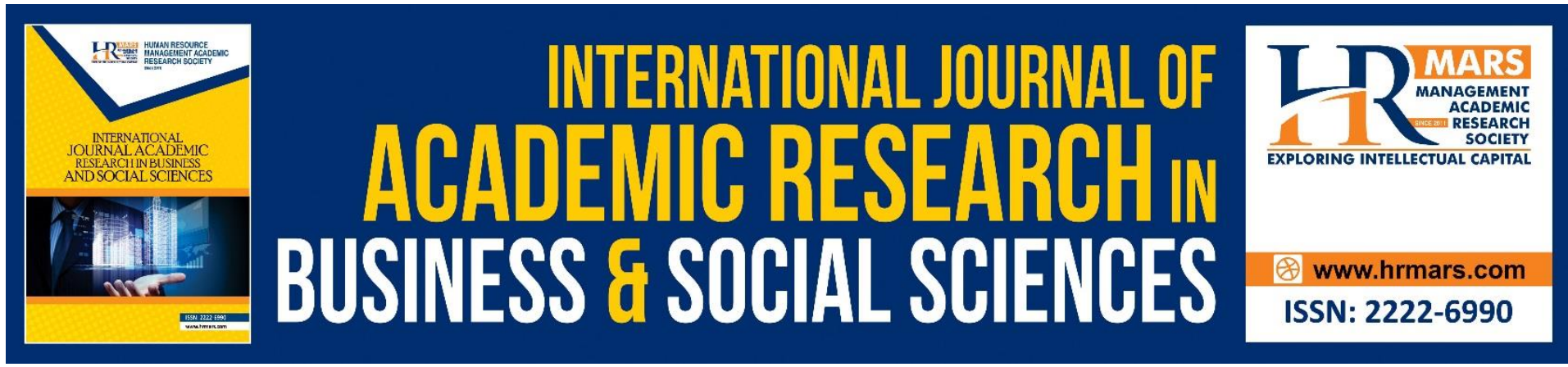

\title{
Family Structure of The Malaysian Indian Youth Involved in Gangsterism
}

\section{Veera Sundari Suppiah, Paramasivam Muthusamy \& Ismi Arif Bin Ismail}

Institute for Social Science Studies, Putra Infoport, Universiti Putra Malaysia, 43400 Serdang, Selangor, Malaysia

Email: sundri05@yahoo.com.my

\begin{abstract}
Gang culture and gangsterism among Indian youth has become very popular in the country over the past few years. This study attempts to describe the effect of family structure on the Indian youths who are involved in gangsterism. The study employs an inductive approach based on a combination of subjectivism and interpretivist philosophies in a qualitative research (semi structured, face to face individual interview guide). The findings showed that the family has direct and incredible influences to initiate them into crime. Their childhood and family background, their current family relationships, and associations between background or family characteristics are being the main factor. The failure to provide proper communication and a concrete family structure tremendously increases the ratio of youngsters engaging in gangsterism. The data for this study were collected from the Indian youths' those are already members of gangs and practice gangsterism.
\end{abstract}

Keywords: Indian Youth, Family Structure, Gang, Gangsterism

\section{Introduction}

Gangsterism is a global phenomenon. It is a culture that belongs to a group of criminals. These groups are known as gangs. Gangs are a group of individuals who share common identity and involve in criminal activities. Most of the gang members tend to be young adults. Involvement of adolescent in gangs are increasing to an alarming level. These gang members are known for being hardened law breakers with little to no regard for human life (Parkinson, 2016). Gangs are getting to be more predominant, progressively savage, and more modern in their crime. In Malaysia, the gang related activities came to public attention since 2013 after Bukit Aman revealed about the gangsterism acts in Malaysia. The assassination cases, armed gang robberies, gang fight and drug related activities became a regular coverage of social media and official news.

The involvement of young children especially school going children and drop out youths being in gang and actively involving in gang activities increased to an alarming level where they need to be given serious attention. Statistics provided by the Ministry of Home Affairs shows that the Indian community has the highest rate of gangsterism among the ethnic group in Malaysia (Shankar, 2019). In 2017, 52 teenagers age between 15 to18 has been 
charged for involving in unlawful activities. 42 of them are school students, 9 school dropout and 1 college student (Mohd, 2017). These teenagers were celebrating the anniversary of Gang 24 in four school compounds. Not many researches and studies has been done about gangs and gangsterism in Malaysia. There are some studies that has been done to highlight the factors that cause the youngsters to join gang. The general factors are usually highlighted in cases like this but the primary cause is not revealed in depth. Therefore this study is focusing on family structure and how it affects youth to involve themselves in gangsterism.

This study sought to explore the family structure and the involvement of youths in gangs. Families are one of the most grounded mingling powers throughout everyday life. Adults in the family teach children to have acceptable behaviour, to have respect on everyone and delay gratification. At the same time the adults in the family also can be a wrong example for children to adapt wrong attitude and behaviour unknowingly as they believe the adults in the families are always looked upon as role models.

In spite of the fact that there are a few compelling variable that cause one to turn into a criminal, the fundamental classification is the family. Family functioning, effect of family interruption and single parents are known as the primary classes that could lead to delinquent conduct due to the exposure of the children to unhealthy relationships that they have come across. Family is a group of one or more parent and their children living together as a unit. These people are related by blood or by marriage, residing in the same house. According to Merriam Webster (2012), family defined as the basic unit in society traditionally consisting of two parents rearing their children. The family has been a basic component for youngster improvement and as a deciding variable for kids' ensuing inclusion in wrongdoing.

Structural of a family is the characteristics of the family members such as those who share a place of residence, or who are related through blood ties or legal contracts. According to Census Bureau (1990), family structure is defined as a householder and one or more other persons living in the same household who are related to the householder by birth, marriage or adoption. In traditional families, husband will be the breadwinner, wife as a homemaker and living with their children. Dual earner families, single parent and remarried families are also called traditional families. The traditional families have their responsibilities such as intimacy and affection, security, childbearing and child-rearing (Suzanne K, 1998). In addition, the role of traditional family is to assure social interaction between family members, providing physical needs and care, providing resources, maintaining morale and motivation and relating to external society and its institution.

John Broadus Watson, American psychologist who popularized the scientific Theory of Behaviourism explained that passive children can be moulded by controlling stimulusresponse association. Parents are in the main position to mould their children's behaviour. Children easily can be taught to become a responsible human. Decision making is one of the skill that children need to learn. Parents have to give opportunities to their children in oreder for them to make their choice and also learn to accept the consequences of the choices. Children on the other hand, need their parent's guidance and advice to succeed in their tasks.

Family plays an important role to teach and nurture children with norms and values. Respect, fairness, compassion and responsibility are part of norms that are copied from the family members and are also instilled in children. The knowledge of life that they learn from their family especially their parents, will guarantee the children's lifestyle in future. When a parent fails or misses their responsibility towards children's development, this is the situation which will encourage their young children to adapt a lifestyle which will lead them to a wrong path as they don't have proper guidance. Parents who instil antisocial attitudes and behaviour 
in their children encourages such attitudes which may persist into adulthood (Chaffin et al, 2004). This kind of family is called a dysfunction family.

This study focuses on the family structure of the Malaysian Indian youth who are already being gang members. This study also aims to understand how the family structure contributes how one choses their life path and future.

\section{Methodology}

The research design that used to do this study was qualitative research. This study aimed to extract the contribution of their family that be the main cause for the youth get involve in gangsterism. This study used purposeful sampling, which involved identifying informants who can give the most comprehensive and also knowledgeable. The study used semi structured interview. The open ended interview questions were used to obtain the information. Ten informants involved in this study. All the informants are Indian youth. The information that gathered from their experience as ex-gangster will be more reliable and valid. The informants were adolescence age between $16-19$ years old boys. They were dropped from schools and didn't complete their secondary school certificate.

These informants are currently going through rehabilitation process from a local rehabilitation centre. Informants were recruited by the centre based on the record, confession and observation on physical. Informants came forward voluntarily to share their experience. Their data and information were being confidential to take care of the betterment of the informants.

\section{Findings}

The finding from this study shows that all the ten informants are from dysfunction family. Five of them are from single parents where their father has left the family and mother has to raise the children on her own. Three informants are from two parent family and another two informants are from step family.

Table 1: Basic Information about the Families of the Informants

\begin{tabular}{|l|l|l|l|l|l|}
\hline Num & Informant & Age & Father & Mother & Siblings \\
\hline 1. & K & 17 & Yes & Yes & 8 \\
\hline 2. & T & 18 & No & Yes & 6 \\
\hline 3. & N & 16 & Yes & Yes & 4 \\
\hline 4. & R & 17 & Yes & Yes & 3 \\
\hline 5. & G & 16 & Yes & Step & 5 \\
\hline 6. & L & 17 & No & Yes & 4 \\
\hline 7. & S & 17 & No & Yes & 5 \\
\hline 8. & A & 18 & No & Yes & 3 \\
\hline 9. & B & 19 & Step & Yes & 5 \\
\hline 10. & C & 19 & No & Yes & 4 \\
\hline
\end{tabular}

Table 1 shows the basic information about the families of the informants. Informant T, L, S, A and $C$ are from single parent. The number of family members is average 4 . Informants $K, N$ and $\mathrm{R}$ from two parents and informant $\mathrm{G}$ and $\mathrm{B}$ are from step family. The family structure of these informants is mixed. Single parent, step family and two parent families. The in depth interview and discussion identified that the relationship between parent and children is cold. 
The findings from the interview indicates that three of them have parents who are likely to understand their needs and two informants expressed their dissatisfactory feeling towards their parents restriction and five more informants feel that their parents don't really bother about their activities with friends and gave them all the freedom without proper guidance.

Informants $\mathrm{K}, \mathrm{N}$ and $\mathrm{R}$ are from two parent families. They are living with their biological parents. It is understood that the parents of these informants rarely spend their time with the children. The communication between parents and children is very basic and does not show proper attention and care for them to guide them or advise them about their actions and decisions.

"K" is from a very poor family. His father is an alcoholic and an abusive person. He doesn't show any responsibility towards family and children. " $K$ " is the eldest child of 8 siblings. He is the bread winner of the family. He was doing a part time job in a firm while studying. But to one extend he was not able to continue his studies. He stopped schooling after his PT3 exam. His mother was taking care of the children on her own. He spent most of his nights with friends because his house is too small and unable to accommodate everyone. When he got to know friends from gangs, he decided to join them. He started to earn money illegally as it was an easier way for him to get money without education.

Informant $\mathrm{N}$ is from a poor family. Both his parents are working. The income is not enough to support the family therefore his father has to do dual job. He hardly meets his father. Most of his communication is only with his mother. His mother is also working and unable to spend time with him and other children too. According to $\mathrm{N}$, most of his leisure hours are spent with his peer group. That is how he got involve in gangsterism.

Informant $\mathrm{R}$ has both parents. They both are working. Mother is a kindergarten teacher and father is a police officer. Financially they are stable but both his parents are very strict towards him. It is not easy for him to get anything he wants to do. He feels very caged as he does not have the freedom to make his life decisions. He did not have a chance to be with his friends. So he used his school hours to be with his friends. He started lying to his parents to spend time with his friends. Sometimes, he will skip his classes and go out with his friends. Gradually he joined gangs to have more fun with group of friends. He also started to earn money from the gangs which made him feel this is an easier path.

Informants T, L, S, A and C are from single parent. All the five of them only have a mother. Informant T's father died of illness, S's father died of accident. Informants L, A and C's father left the family. For a single parent especially mother, taking care of the children is a great challenge. The number of children in each family shows the responsibilities of the parent are higher. Providing proper food, shelter and fulfil other physiology needs could be beyond their ability. Since there is no father in the family, children lost the love of another parent. It affected them and they started to seek love outside the family. Their mother is not able to give attention fully as she will have to work to support the family, thus the attention and care shown upon her children are much lesser. Children who don't get enough attention tend to take the wrong path in life due to the freedom of making their own choice regardless, positive or negative as there is no one to guide them.

Informant $G$ and $B$ are from step family. G's mother died when he was only 5 years old. He is the third child in the family. He has two elder brothers and two younger sisters. His father worked as a rubber tapper with only few hundred ringgit as monthly income. His elder brothers were staying with his grandparents. $G$ was living with his father and step mother. He was going to school until form two. Later, he ran away from the house and stayed with his 
grandparents. Grandparents were not strict and he started to join his friends who were already gang members.

$B$ is also from a step family. His mother married to his step father when B was 10 years old. They have four children and B always felt left out in the family. He spent his childhood at his grandparent's house. His uncles are gang members and he gradually got to know friends who are also gang members and joined gang at the age of 16 due to the exposure at a young age.

Even though the informants are from different backgrounds and family structure yet they have joined gangs. The common factor between them is because they did not get full attention and love from their loved ones.

\section{Discussion}

Child development includes emotional, intellectual, social and physical aspects, and the family is the foundation of development. Family structure plays an important role in the formation of children by providing a sense of security and developing children's values and abilities (Rosemary, 2019).

Based on the study, it is evident that adolescents from a dysfunctional family do not show a positive progress in their childhood. The relationship between a changed family structure and a child's behaviour has more effects compared to a child that has a negative behaviour from the start. Family plays a major role in shaping the child's personality and interest. A family is commonly known as the backbone of a family and holds the responsibility to shape the child's future (Cashen, 2019).

This study has also shown how when a change occurs in a family structure, the outcome of the child in that particular family also changes. The different structures of a dysfunctional family, results in poor outcome of the child. The family structure defines and moulds the child's personality and behaviour, thus this study found significant relationships changes when a family structure is changed in a negative way.

According Alisha (2013), adolescents from two biological parent families were less likely to participate in crime compared to youth from single parent. This is probably because two parent families have more moral values that are positive compared to other family types. In this study, from ten informants, only three are from two parent family. Children with two parents are better placed to avoid some of the "growing up disaster". Wardle (2004), claim that children need a stable marriage between their mother and father to be able to enjoy the best preparation and opportunities for life success and happiness.

There are also two parent families who produce delinquent children. These families are more likely to have irresponsible parents who neglect children's welfare. For children, the family is the major source of companionship, affection and reassurance. When parent fail to occupy these to their children, it encourages the children to become a delinquent. Children from this kind of background will feel emotionally insecure (Akinyi, 2015).

The informant $\mathrm{K}$ from two parent families had high level violence in his family. His father is an alcoholic who abuses his mother and children. He does not have any affection towards his family. This attitude pushed $K$ to find job and help his mother to support his family. According to $\mathrm{K}$, he even joined gang to gain money. Even though he knew it is wrong but he had no other choice.

The other informant $\mathrm{N}$ is living with his both biological parent yet he joined gangs because he feels that he did not get the love and attention that he wants. Poverty drives his parent to work extra to earn money for the family. His parents were working whole day and 
they were not able to find time to spend with their children. He did not get a chance to enjoy his life as he wanted. However, he joined gangs in order to try to fulfil his needs. According to Birckhead (2012), inability to afford certain basic commodities such as food and clothing, has significantly contributed to juvenile delinquency.

Informant $\mathrm{R}$, is different from the other two parent family members. His parents are educated and financially stable. But their attitude towards his children is more towards authoritarian. He did whatever he wants and makes him happy without his parent's knowledge. For that he skipped his classes, joined wrong friends and finally ran out of his house and joined gang. Birckhead (2012), did mention that parent who is an authoritarian, control their children excessively. Their communication with the children is more of a way. Their harsh orders and harsh words deprived the children of their freedom to express themselves. The suppression of freedom of speech and lack of love encouraged children to rebel against their parents, flee their families, and enter criminal lives.

Adolescents from single parent are most likely to lose a lot of values as a family. Children who experience family breakdown in all its forms are twice likely to have behavioural problems, perform less well in school, suffer from depression and turn on drugs, smoking and heavy drinking (Van de Weijer, 2015). Single parent could be father or mother without spouse. The single parent situation could occur due to divorce, death or separation. When a parent is single, they have to take care of his or her children, the burden is likely doubled compared to two parent family. Parents need to do double job in order to support the family. The stress level and pressure is definitely higher than normal parent. Children from this broken family are more likely to suffer from impaired psychological development and be at increased risk of being violent.

The finding from this study has proven that from ten informants, five of them are from single parent family. These informants are left alone because the parent has to spend more time to earn money to support the family. This open a wide opportunity for the children to mix with wrong friends. They are always finding easier ways to earn money. These children do not know the dangers of being in gang because they get the full support from their seniors in the gang.

Some of their parents are just uninvolved in their growth and life. They emotionally have distant themselves from their children and show very little almost to none care and love towards them, provide little supervision, intentionally avoid their children. These parents have very few expectations, never attend school events and are always too overwhelmed by their own problems. (Hearne, 2015)

Children from single parent also may not get enough love and attention that they should get. According Malaysian police personnel (Shankar, 2019) parents who were not attentive and who did not discipline children for their wrongdoings were cited as the main reasons behind the involvement of teenagers in gangs.

The informants did mention that they have no one at home to spend time and to understand them more. They do not get a chance to share their happy or sad moments. The informants also agree that they are seeking appreciation and praise for what they have done but their parents are not attentive. Parents only want them to study but their other skills and talent are not noticed. But this situation does not only happen in single parent family but also in two parent and step families as well.

When a lone parent begins living with, or marries, another lone parent, a stepfamily is formed. Stepfamilies can be formed in a variety of ways, with men and women entering as stepparents or biological parents. For some, becoming a stepparent is their first taste of 
parental and conjugal life and for others, it is their second. "A married or common-law couple residing in the same household with at least one step child who is the biological or adopted child of one parent but not the other parent" is the generic term for step family. A blended family is a subset of a step family, and it refers to families with children who do not have the same biological parents (Heather, 2001)

When it comes to step family, for Malaysian Indian community, living with step family is not easy in many step families, the children will be sent to their grandparent's house or the children themselves moved to grandparent's house. There are grandparents who give regular daily care to grandchildren. This category is where parents leave their children away and pick them up later. This is because it is not very acceptable in many families and not a norm as part of the Indian community tradition.

"Living-with" grandparents, who reside with a grandchild but do not have legal custody. This is the most common where grandchildren live with grandparents without legal custody. Usually the grandchild lives in the grandparent's home, which provide regular daily, care for long-term. Grandparents who take the responsibility to take care of grandchildren are called "grandfamilies" which relative take over primary responsibility for raising a child from parents (Divya, 2021).

Grandchildren come with common stress. Taking care of the children in every aspect makes them feel tired at an old age. Grandparents usually anticipate later life as a time to enjoy the privileges of grandchildren without many responsibilities. Taking care of grandchildren as living with may cause inconvenience where these grandparents need to adjust their life planning to support them.

Some grandparents, who are not able to cope the new life style and responsibility, do not involve much in grandchildren's lives. As the grandchildren grow, they are given freedom to do what they want. Grandparents are more in need to support in caring their own physical and emotional health (Divya, 2021).

Informant $\mathrm{G}$ and $\mathrm{B}$ grew up in grandparent's house. They were given full freedom and are pampered by their grandparents. The freedom they have in grandparent's house leads them to join with the wrong group of friends. These friendships influence them to join gang later. Informant $B$, has an advantage to join gang since his uncle is also gang member. When $B$ is with his uncle, he is surrounded by his uncle's friends. This situation makes $B$ to feel that gangsterism is a common among adults. He was not aware of the seriousness as his family member is also a gang member.

\section{Conclusion}

This study was to explore the family structure of the ex-gangsters who are in rehabilitation centre. As the study emphasize in depth investigation in a small number communities, the purpose of these studies is not generalization of the finding. Appropriately there are no claims that the information from this study will mirror the experience of all the gangsters in Malaysia. The present study relies on the experience of the informants who were ex-gangster members. The data is consisting of the individuals' experiences, perceptions and thoughts. Therefore the experience of the informants is biased by their situation and the way they experience and observe the events.

Based on the finding the ratio 5:10 of the youth who involves in gangsterism are from single parent family. 3:10 ratio of the informants is from two parent dysfunction families, and step family with ratio $2: 10$. The implications from these findings may suggest that the relationship between family structure and involvement of youth or children into gangsterism 
has to be given importance. Parents should be given awareness of the impact of their family structure towards their children's development and emotional support. Parents also need to be educated of their responsibility to protect their children from getting involved into criminal act as they have the full responsibility to guide their children and their future.

Children especially youth need more guidance to shape their behaviour and attitude. Importance of education need to be taught regardless of how their families are structured. School as the second family needs to play an important role to educate these children. Even though school cannot do much to change their family structure but they can create awareness in children about education and morale values. Counsellors in school can guide the children to make the right choice and decision before they come out with wrong decision. Children should know the way to adapt the situation and move forward with positive attitudes.

\section{Reference}

Abdullah, M., \& Rahman, N. A. (2016). Family Role in Deviant Behaviour Development of Adolescents, Referring Juvenile Delinquency: A Qualitative Approach. Science International. 28(6), 5189-5195.

Ahmad, K. (2020). Family Life in Islam. https://www.iium.edu.my/deed/articles/family_islam/ch04.ht

Akinyi, O. D. (2015). Effects of Authoritarian Parenting Model on Learner Participation in Early Childhood Education Science Class Kabondo Division. Effects of Authoritarian Parenting Model on Learner Participation in Early Childhood Education Science Class Kabondo Division. Published. http://erepository.uonbi.ac.ke/bitstream/handle/11295/95154/

Parks, B. A. (2013). The Effects of Family Structure on Juvenile Delinquency. The Effects of Family Structure on Juvenile Delinquency. Published. https://dc.etsu.edu/cgi/viewcontent.cgi?article $=3380 \&$ context=etd

Boccio, C. M., \& Beaver, K. M. (2017). The Influence of Family Structure on Delinquent Behavior. Youth Violence and Juvenile Justice, 17(1), 88-106. https://doi.org/10.1177/1541204017727 836

Chaffin, M., Silovsky, J. F., Funderburk, B., Valle, L. A., Brestan, E. V., Balachova, T., Jackson, S., Lensgraf, J., \& Bonner, B. L. (2004). Parent-Child Interaction Therapy with Physically Abusive Parents: Efficacy for Reducing Future Abuse Reports. Journal of Consulting and Clinical Psychology, 72(3), 500-510. https://doi.org/10.1037/0022-006x.72.3.500

Danladi, A., Jonathan, F., Momade, H., Linda, I. N., Win, K. N., \& Funmilayo, O. (2021a). MALAYSIAN INDIANS. History of Their Migration \& Their Impact on Malaysia's Development. https://www.academia.edu/25574486/Malaysian_indians

Wardle, D. L. (2004). Children and The Future of Marriage. Children and The Future Of Marriage, 17(279). https://www.regent.edu/acad/schlaw/student_life/studentorgs

Fagan, P. (1995). The Real Root Causes of Violent Crime: The Breakdown of Marriage, Family, and Community. The Heritage Foundation. https://www.heritage.org/crime-andjustice/report/the-real-root-causes-violent-crime-the-breakdown-marriage-family-and

Gaille, L. (2016a). How Poverty Influences Crime Rates. Personal Finance Blog.org. Published. https://vittana.org/how-poverty-influences-crime-rates

Herke, M., Knöchelmann, A., \& Richter, M. (2020). Health and Well-Being of Adolescents in Different Family Structures in Germany and the Importance of Family Climate. International Journal of Environmental Research and Public Health, 17(18), 6470. https://doi.org/10.3390/ijerph1718 6470 
Juby, H., Le Bourdais, C., \& Marcil-Gratton, N. (2001). A step further: Parenthood in blended families.

https://www.researchgate.net/publication/266494745_A_step_further_Parenthood_i n_blended_families

Jansen, K. (2017). Extended Family Relationships: How They Impact the Mental Health of Young Adults. Theses and Dissertations Family Sciences Family Sciences. 1 - 64. https://doi.org/10. 13023/ETD.2017.102

Jensen, T. M., \& Lippold, M. A. (2018). Patterns of stepfamily relationship quality and adolescents' short-term and long-term adjustment. Journal of Family Psychology, 32(8), 1130-1141. https://doi.org/10.1037/fam0000442

Mayowa, I. O. (2020). Single Parenthood and Juvenile Delinquency in Southwest Nigeria: A Sociologigal Perspective. ResearchGate.

https://www.researchgate.net/publication/34336

1180_SINGLE_PARENTHOOD_AND_JUVENILE_DELINQUENCY_IN_SOUTHWEST_NIGERI A_A_S OCIOLOGIGAL_PERSPECTIVE

Mitton, B. L., \& Harris, D. B. (1954). The Development of Responsibility in Children. The Elementary School Journal, 54(5), 268-277. https://doi.org/10.1086/458585

Mwangangi, R. (2019) The Role of Family in Dealing with Juvenile Delinquency. Open Journal of Social Sciences, 7, 52-63. https://doi.org/10.4236/jss.2019.73004

Philipp, J. (2019). 10 Facts About Poverty in Malaysia. The Borgen Project. https://borgenproject.org /10-facts-about-poverty-in-malaysia/

Reeta, D. V., \& Singh, D. G. (2020). Broken Families and Impact on Juvenile Delinquency. International Journal of Humanities and Social Science Invention (IJHSSI), 9(5). https://www.ijhssi.org/papers/vol9(5)/Series-3/F0905033338.pdf

Ryan, R., Claessens, A., \& Markowitz, A., J. (2014). Family Structure and Children's Behavior. Institute for Research on Poverty. 30(2). 11-14.

Saxena, D., \& Brotherson, S. (2021b). When Grandparents Become Parents to Their Grandchildren. North Dakota State University.

https://www.ag.ndsu.edu/publications/home-farm/when- grandparents-becomeparents-to-their-grandchildren

Smith, R. H. I. D. (2007). Being tough on the causes of crime: Tackling Family Breakdown to Prevent Youth Crime. Social Justice Challenge. $1-15$.

https://www.centreforsocialjustice.org.uk/wpcontent/uploads/2018/03/causes_of_crime.pdf

Steinmetz, S., \& Stein, K. (1988). Traditional and Emerging Families: A Typology Based on Structures and Functions. Family Science Review, 1(2).

https://doi.org/10.26536/fsr.1988.01.02.02

Van de Weijer, S., Thornberry, T., Bijleveld, C., \& Blokland, A. (2015). The Effects of Parental Divorce on the Intergenerational Transmission of Crime. Societies, 5(1), 89-108. https://doi.org/10.33 90/soc5010089 